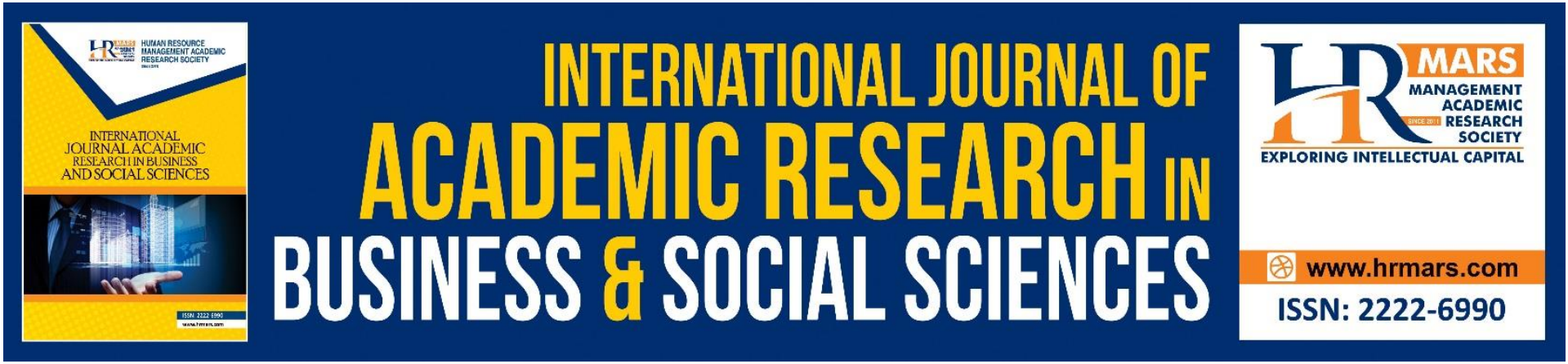

\title{
A Closer Look on Health Risk Attitude and Its Relationship towards Stress-Related Behaviour among Youth
}

Siti Musliha Mohd Idris, Khairunnisa' Yussof and Noraznira Abd Razak

To Link this Article: http://dx.doi.org/10.6007/IJARBSS/v11-i12/11713～DOI:10.6007/IJARBSS/v11-i12/11713

Received: 09 October 2021, Revised: 14 November 2021, Accepted: 27 November 2021

Published Online: 19 December 2021

In-Text Citation: (Idris et al., 2021)

To Cite this Article: Idris, S. M. M., Yussof, K., \& Razak, N. A. (2021). A Closer Look on Health Risk Attitude and Its Relationship towards Stress-Related Behaviour among Youth. International Journal of Academic Research in Business and Social Sciences, 11(12), 2401-2410.

Copyright: @ 2021 The Author(s)

Published by Human Resource Management Academic Research Society (www.hrmars.com)

This article is published under the Creative Commons Attribution (CC BY 4.0) license. Anyone may reproduce, distribute, translate and create derivative works of this article (for both commercial and non0-commercial purposes), subject to full attribution to the original publication and authors. The full terms of this license may be seen at: http://creativecommons.org/licences/by/4.0/legalcode

Vol. 11, No. 12, 2021, Pg. 2401- 2410

http://hrmars.com/index.php/pages/detail/IJARBSS

Full Terms \& Conditions of access and use can be found at http://hrmars.com/index.php/pages/detail/publication-ethics 


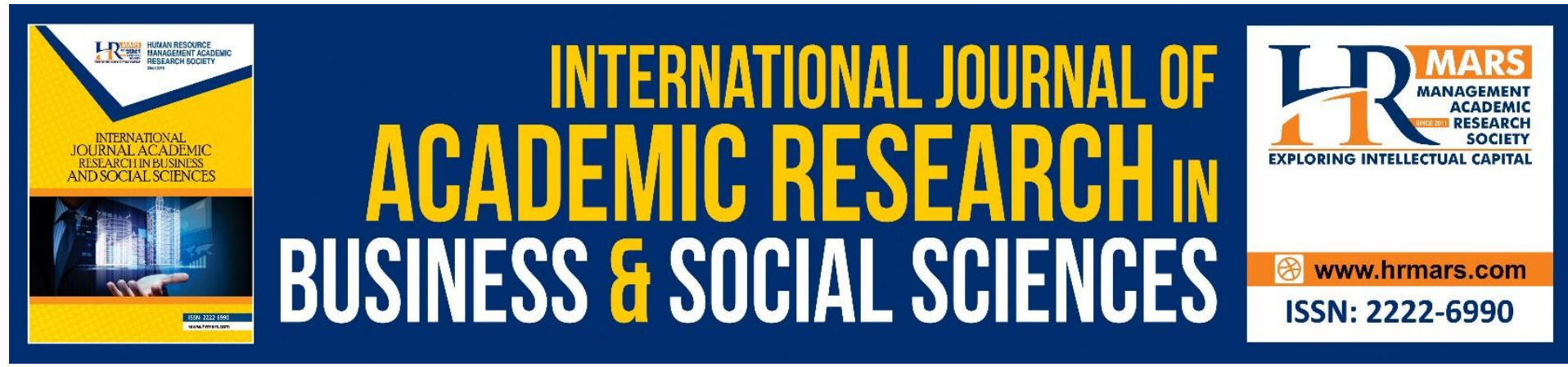

\title{
A Closer Look on Health Risk Attitude and Its Relationship towards Stress-Related Behaviour among Youth
}

\section{Siti Musliha Mohd Idris, Khairunnisa' Yussof and Noraznira Abd Razak}

Faculty of Business Management, University Technology MARA, Melaka, Malaysia Email: sitimusliha@uitm.edu.my, khairunnisayussof@uitm.edu.my,noraznira@uitm.edu.my

\begin{abstract}
COVID-19 outbreak has created tremendous implications for the entire world population. It has caused many to lose their jobs, precarious health, family problem, and many more. The stress resulting from this pandemic has disrupted the emotional well-being of individuals such as depression. The identification of youth behavior towards health risk such as depression is vital important as it need to be address to ensure our future human capital mentally equips with positive mental health that shall lead to positive attitude and resilience in their future endeavour. The purpose of this research is to investigate the factors that may contribute towards the preventive behavior of stress-related behaviour namely depression among youth by adopting the Health Action Process Approach (HAPA) theory. It is important to see the pattern of this behavioural element from risk perspective among future human capitals as it shall reflects on the productivity and competency of our future workforce in the years to come. This study applies analysis technique using SmartPLS 3.4 version involving 186 respondent among youth of 15-30 years old in Malaysia. This study partially adopted HAPA as main underlying framework to further explained the variables involved.
\end{abstract}

Keywords: Mental Health, Depression Risk, Health Action Process Approach Theory, StressRelated Behavior

\section{Introduction}

The outbreak of coronavirus disease (COVID-19) came out as the most devastating and challenging crisis for public health in the contemporary world. Apart from the soaring mortality rate and affected health risk, nations across the globe have also been suffering from a spike of the excruciating psychological outcomes, i.e., anxiety and depression among people of all ages (Wong \& Alias, 2020).Youth are no exception, as all the educational institutions are unprecedentedly closed for more than usual, and for Malaysia, it is more than year and half in a row back to back the MCO is executed. According to UNICEF (2018), The Youth Societies and Youth Development (YSYD) Act 2019 defined youth as persons aged 15 to 30 years of age whereby it is a stage during which young people go through many physical and psychosocial changes. It is a critical period that is associated with 'growing opportunities, capacities, aspirations, energy and creativity, but also significant vulnerability. The unprecedented 
experience of being quarantined at home in confined conditions with uncertainty and increased workload includes the shifting of learning systems has given impacts on various aspects including the mental health of citizens, particularly youth namely those who still studying. Mental health issues among youth have long been a concern in Malaysia, this is a problem that is getting attention to be put on it (Johari et al., 2020; Latiff et al., 2017). And it is often linked that adolescence is often characterized as a time of storms and stress," as it usually provokes more chaos than other developmental stages (Othman \& Essau, 2019).

The purpose of this study focuses on health risk namely depression among youth that might affect the self esteem, the confidence level that become of strong element in intrapersonal skills of an individuals. Although it is still a taboo in certain developing communities but is an issue that need to be addressed not only in the years to come but more so in our current pandemic situation. A wide range of health professionals have focused on changing health behaviour by targeting the intrapersonal level, where several theories have been developed to help find an effective intervention. HAPA, which contains several key concepts that address why people will take action (behaviour) to prevent, screen for, or control illness, are used in this study (Sonia, 2020). Given the unforeseen circumstances, it is critical to investigate the health risk attitude of youth, particularly during the COVID-19 pandemic. This current study is motivated primarily by two factors: the importance of youth development to the development of the country, and the importance of youth mental health to that development. Additionally, it is expected that this study will investigate whether risk perception, outcome expectancies, self-efficacy and the desire to change one's health risk attitude particularly on behaviour changes in order to minimise stress-related behaviour such as depression.

\section{Literature Review}

Many past studies have suggested and emphasized the importance of studying and improving the mental health levels of youth, especially those leading to depression (Johari et al., 2020). As Othman \& Essau (2019) points out about youth health, both physical and mental health must improve significantly in order for them to thrive and reach their full potential. Despite the availability of evidence-based prevention and intervention programmes and studies, Malaysia still lacks programmes and studies focusing on health behaviour change. Various issues such as increasing workload as mentioned in the summary of the proposal, the present situation also lead to depression. Therefore, it is important to help change their attitude to protect them from being overwhelmed by depression (Wong et al., 2021), In the behavioural change study, to explain the present framework this study uses Health Action Process Approach (HAPA). In the HAPA model, there are several studies linking the relationship between self -efficacy, risk perception and outcome expectancies with preventive behaviour.

\section{Applying HAPA Constructs}

Youth may wish to avoid stress-related behavior namely depression if they believe in the prevention benefits of mental health risk. To prevent depression, this youth must understand their perceived risk, their outcome expectations, and their self-efficacy to change their attitude and take preventative action. In the motivational phase, the HAPA suggests three factors that predict the intention to change behavior. The author discusses three factors that 
influence preventive behaviour in this study: self-efficacy, risk perception, and outcome expectations.

\section{Self-Efficacy and Preventive Behaviour}

As previously stated, self-efficacy should be viewed as a cognitive precursor to anxiety and depression (Tahmassian \& Moghadam, 2011). This is because self-efficacy refers to a person's belief in his or her ability to successfully perform the target behaviour and overcome obstacles and barriers to success. (Hamilton et al., 2020). In the study by Kim \& Kim (2020) has mentioned that self-efficacy influence to health promoting behaviour. In other words, self-efficacy has a positive effect on youth' willingness to engage in preventive behaviour. As a result of this research, the following hypothesis is:

\section{H1 Self-efficacy has a Positive Relationship with Preventive Behaviour}

Risk Perception and Preventive Behaviour

There is a dearth of information regarding the accuracy of risk perceptions for stress-related attitude namely depression, as well as how this risk perception demonstrates in the self-help behaviours (Warner et al., 2020). Risk perceptions are beliefs regarding susceptibility to particularly specific conditions or outcomes (Zhang, Zhang, Schwarzer, \& Hagger, 2019). Basically, in HAPA model, the intention to change behavior influence by various predictors and it will centralizes on the beliefs in motivation phase to make a person perform specifically (Rohani et al., 2016). Understanding youth' stress-related behaviour and how it relates to their risk perception is also critical as part of effective outbreak disease control for their age group (Cvetković et al., 2020). Thus, this research proposes the following hypothesis:

\section{H2 Risk Perception has a Positive Relationship with Preventive Behaviour}

\section{Outcome Expectancies and Preventive Behaviour}

Outcome expectancies reflect beliefs about whether or not engaging in the behavior that will result in desired outcomes (Zhang et al., 2019). Outcome expectancies is the beliefs that the target behavior will lead to outcomes that have utility for the individual, conceptually identical to an individual's attitudes toward the behavior (Hamilton et al., 2020). It concerns a youth' belief in relation to positive or negative consequences due to a certain behaviour. Although some previous research indicates that outcome expectations are unrelated to the ability to change behaviour, it has been suggested that further validation be conducted because outcome expectations have varying effects across fields of study (Lao et al., 2021). Thus, this research proposes the following hypothesis:

\section{H3 Outcome expectancies has a positive relationship with preventive behaviour}

As such, this study will examine the relationship between self-efficacy, risk perception, and outcome expectations in order to determine the effect of these three constructs on prevention behaviour in youth.

\section{Methodology}

This research applied self-administered questionnaire in collecting the data. This research used the SmartPLS3.4 to analyze the data. The distribution of questionnaire up to 650 for the 
youth age range of respondent and a total number of valid responses was 186 responses. The response rate was 28.6 percent.

\section{Results and Discussion}

The demograhic results showed that more than half of the sample $(81.7 \%)$ was from female respondents and $95.7 \%$ of overall respondents comes from the age $18-25$ years old. The demographic data of the respondents showed that all of the respondents come from the diverse educational background. More than 68 percent of the respondents comprised of diploma holder and the rest comes from undegraduates and postgraduates level of education.

\section{Assessment on Reflective Measurement Model}

All item loadings were greater than 0.70 and significant at the 0.01 level, indicating convergent validity at the indicator level. All average variance extracted (AVE) values were greater than 0.50 , suggesting convergent validity at the construct level. A measurement model has satisfactory internal consistency reliability when the composite reliability (CR) of each construct exceeds the threshold value of 0.7. All CR values that are greater than 0.70 indicate an acceptable reliability. Thus, the results indicate that the items used to represent the constructs have satisfactory internal consistency reliability.

Table 1

Fornell-Larcker Criterion

\begin{tabular}{|c|c|c|c|c|}
\hline & $\begin{array}{l}\text { OUTCOME } \\
\text { EXPECTANCY }\end{array}$ & $\begin{array}{l}\text { PREVENTIVE } \\
\text { BFHAVIOUR }\end{array}$ & $\begin{array}{l}\text { RISK } \\
\text { PFRCFPTION }\end{array}$ & $\begin{array}{l}\text { SELF } \\
\text { FFEICACY }\end{array}$ \\
\hline OUTCOME & 0.780 & & & \\
\hline EXPECTANCY & & & & \\
\hline PREVENTIVE & 0.633 & 0.836 & & \\
\hline BEHAVIOUR & & & & \\
\hline $\begin{array}{l}\text { RISK } \\
\text { PERCEPTION }\end{array}$ & -0.133 & -0.149 & 0.764 & \\
\hline $\begin{array}{l}\text { SELF } \\
\text { EFFICACY }\end{array}$ & 0.629 & 0.620 & -0.172 & 0.793 \\
\hline
\end{tabular}

Based on Table 1, an off-diagonal elements are lower than square roots of AVE (bolded on the diagonal). Hence, the result indicating an adequate discriminant validity for all of the reflective constructs. As for table 2, the HTMT criterion also indicates that the confidence interval does not show the value of 1 on any of the construct which also confirms discriminant validity. 
Table 2

Heterotrait-Monotrait Ratio (HTMT)

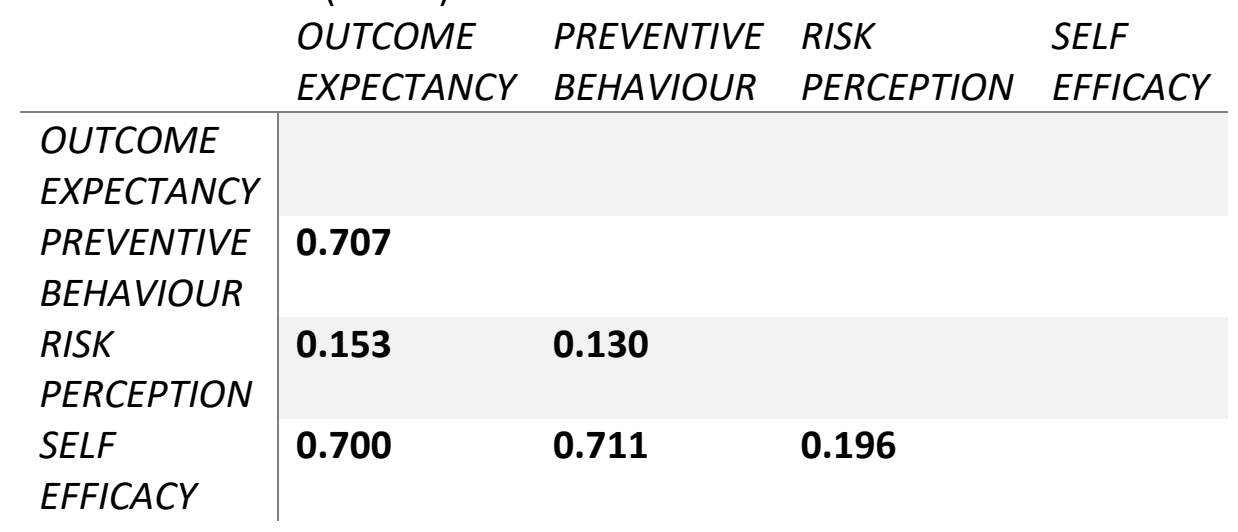

\section{Assessment of Structural Model}

Three direct hypotheses are developed between the constructs. T- statistics for all paths are generated via SmartPLS3.4 bootstrapping analysis. Two out of three hypotheses are found to have $t$-value $\geq 1.645$, thus significant at 0.05 level namely self efficacy construct is positively related on preventive behaviour $(\beta=0.363, p<0.01)$ and as well as outcome expectancy construct also positively related on preventive behaviour construct by $\beta=0.400, p<0.01$ ). On the other hand, risk perception construct is negatively related to preventive behaviour $(\beta=-$ $0.034, \mathrm{p}<0.01$ ), hence the the $\mathrm{H} 2$ is not supported. Thus, $\mathrm{H} 1$ and $\mathrm{H} 3$ are supported. Henseler, Ringle, \& Sinkovics, (2009) indicates that moderate or average $R^{2}$ values are acceptable when the endogenous construct is explained by few exogenous construct. For this research, preventive behaviour explained $48.3 \%$ of the variance in self efficacy, outcome expectancy and risk perception with $R^{2}=0.483$, which is considered as substantial (Cohen, 1988). The $f^{2}$ value of self efficacy stated at 0.152 and outcome expectancy of 0.187 indicates both constructs have a substantial effect in producing the $\mathrm{R}^{2}$ for preventive behaviour. Whilst, the $f^{2}$ value of 0.002 indicates risk perception has a very small effect in producing the $R^{2}$ for preventive behaviour. The predictive relevance $\left(Q^{2}\right)$ of preventive behaviour has a value of greater than 0 which stands at 0.318 , which indicates that the model has a large predictive relevance for endogenous constructs as predictive relevance $\left(\mathrm{Q}^{2}\right)$ should stand above zero (Hair Jr, Sarstedt, Hopkins, \& Kuppelwieser, 2014) . 
Table 3

Path coefficients, Observed t-statistics and results for all hypothesized path

\begin{tabular}{|c|c|c|c|}
\hline HYPOTHESES & $\begin{array}{l}\text { PATH } \\
\text { COEFFICIENT }\end{array}$ & $\begin{array}{l}T \quad \text { Statistics } \\
(|O / S T D E V|)\end{array}$ & RESULTS \\
\hline $\begin{array}{l}\text { OUTCOME } \\
\text { EXPECTANCY } \\
-> \\
\text { PREVENTIVE } \\
\text { BEHAVIOUR }\end{array}$ & 0.40 & 6.503 & SUPPORTED \\
\hline $\begin{array}{l}\text { RISK } \\
\text { PERCEPTION } \\
-> \\
\text { PREVENTIVE } \\
\text { BEHAVIOUR }\end{array}$ & -0.034 & 0.522 & $\begin{array}{l}\text { NOT } \\
\text { SUPPORTED }\end{array}$ \\
\hline $\begin{array}{l}\text { SELF } \\
\text { EFFICACY -> } \\
\text { PREVENTIVE } \\
\text { BEHAVIOUR }\end{array}$ & 0.363 & 4.864 & SUPPORTED \\
\hline
\end{tabular}

Note: $*$ t-values $>1.645(p<0.05) ; * * t$-values $>2.33(p<0.01)$ (one-tailed test)

Results from the study indicate that outcome expectancy and self efficacy construct are among many of the significant predictors in explaining the preventive behaviour towards depression among youth nowadays. Interestingly, these findings affirmed those of Zeidi et al (2021) who found that self-efficacy and outcome expectations are statistically significant predictors of behaviour. According to these findings, youth who believe they can change their behaviour and believe that the positive result of prevention behaviour will help them live a healthy and happy life will be more likely to engage in preventive behaviours such as leading a healthy lifestyle, seeking help, and eating healthy. Individuals with a higher sense of selfefficacy envision the success of an action and are thus more capable of changing their behaviour (Karl et al., 2018).

On the other hand, this study found that there is a negative relationship between risk perception and preventive behaviour. This finding contradicts Mahmood et al (2021) finding that when people's risk perception of disease is high, and as a result, the majority of people took preventive measures and believed they were effective. Our findings indicate that an increase in risk perception did not result in an increase in preventive behaviour. This may occur when youth have little understanding of the seriousness of depression. This may also occur if the respondent relies solely on personal experiences and thus underestimates the prevalence and severity of the risk (Freivogel \& Visschers, 2021). Based on the findings of the current study, it is recommended that future studies employ a broader range of respondents and examine additional factors that contribute to influencing depression prevention behaviour in order to improve their accuracy.

\section{Conclusion}

Youth are a national asset of every country and it is very important to ensure that they are always in good health and mental well-being in order to maintain a healthy minded and resilient society and resulted in successful development of one's country. However, it was found that the problem of stress-related behavior namely depression among youth is already 
a norm in some country. The conditions that stimulate towards depressive problems are such as family problems, friends, financial problems and others. So identifying preventive behaviors in youth is very crucial in order to maintain an all-rounder good quality society.

We developed a research model based on the literature review, so the testing of research hypotheses was done on a sample of youth, following an analysis using the PLS-SEM approach. Results of the study suggest that the predictor namely self-efficacy and outcome expectancies yield significant relationship with preventive behavior. While, the relationship between risk perception and preventive behavior has shown a negative relationship.

The current study contribute significantly to understanding the youth psychological behaviour to prevent stress related behaviour such as depression. First, this finding of the study may lead to an awareness among youth towards the symptoms of health risk attitude namely depression in Malaysia to understand the significance of self-efficacy, risk perception and outcome expectancies towards preventive behaviour in mental health management. As a result, youth compliance and confidence in adapting the preventive behaviour may yield a positive outcome. By reducing unhealthy lifestyle and alerting early symptoms, ultimately, it will improve quality of life among youth that have tendency towards health risk such as depression.

Secondly, this study can help to improve knowledge on mental health, self-efficacy from risk management perspective and may lead to the positivity in risk perception as well as quality of life among youth and reducing the symptoms of health risk such as depression. Hence, this can reduce the burden of parents and the youth as well if it can be prevented during the symptom stage. This article may be fruitful towards different or broaden perspective if it can be conducted in a larger population and various age group apart from youth. Thus, contributing as an important pathway to the government and other healthcare institutions in finding various avenue to ignite awareness as well as escalating positive motivational level of the youth age group will be beneficial towards our society as a whole (Othman \& Essau, 2019). Third, this articles can be of help in assisting mental health educators to develop effective strategies for improving the current preventive behaviour of mental health education. Hence, the result of this study hopefully able to contribute towards the practical and theoretical element of the same research settings in Malaysia.

\section{Declaration of Competing Interest}

None.

\section{Funding Aknowledgement}

This research is supported by University Technology Mara (UiTM) under TEJA Grant (GDT2021/1-15).

\section{References}

Cohen, J. (1988). Statistical power analysis for the behavioral sciences (2nd ed.). Hillsdale, NJ: Lawrence Erlbaum Associates.

Cvetković, V. M., Nikolić, N., Nenadić, U. R., Öcal, A., Noji, E. K., \& Zečević, M. (2020). Preparedness and preventive behaviors for a pandemic disaster caused by COVID-19 in Serbia. International Journal of Environmental Research and Public Health, 17(11), 1-23. http://doi.org/10.3390/ijerph17114124

Freivogel, C., \& Visschers, V. H. M. (2021). Antimicrobial-resistant bacteria in food: which 
behaviour change strategies increase consumers' risk awareness and preventive foodhandling behaviour? Health Psychology and Behavioral Medicine, 9(1), 350-379. http://doi.org/10.1080/21642850.2021.1912609

Hamilton, K., Smith, S. R., Keech, J. J., Moyers, S. A., \& Hagger, M. S. (2020). Application of the Health Action Process Approach to Social Distancing Behavior During COVID-19. Applied Psychology: Health and Well-Being, 12(4), 1244-1269.

http://doi.org/10.1111/aphw.12231

Henseler, J., Ringle, C. M., \& Sinkovics, R. R. (2009). The Use of Partial Least Squares Path Modelling in International Marketing. Advances in International Marketing, 20(1), 277319. http://doi.org/10.1108/S1474-7979(2009)0000020014

Johari, M. Z., Wee, L. H., Nudin, S. S. H., Ujang, E., Roslan, N. M., Omar, B., \& Chinna, K. (2020). High Risk Health Behavior among Malaysian Adolescents: A Comparison between Gender. Global Journal of Health Science, 12(11), 152.

http://doi.org/10.5539/gjhs.v12n11p152

Karl, F. M., Smith, J., Piedt, S., Turcotte, K., \& Pike, I. (2018). Applying the health action process approach to bicycle helmet use and evaluating a social marketing campaign. Injury Prevention, 24(4), 288-295. http://doi.org/10.1136/injuryprev-2017-042399

Kim, S., \& Kim, S. (2020). Analysis of the impact of health beliefs and resource factors on preventive behaviors against the covid-19 pandemic. International Journal of Environmental Research and Public Health, 17(22), 1-21.

http://doi.org/10.3390/ijerph17228666

Lao, C. K., Li, X., Zhao, N., Gou, M., \& Zhou, G. (2021). Using the health action process approach to predict facemask use and hand washing in the early stages of the COVID-19 pandemic in China. Current Psychology, 2004. http://doi.org/10.1007/s12144-021-01985-0

Latiff, L. A., Tajik, E., Ibrahim, N., Bakar, A. S. A., \& Shirin, S. S. A. A. (2017). Psychosocial problem and its associated factors among adolescents in the secondary schools in Pasir Gudang, Johor. Malaysian Journal of Medicine and Health Sciences, 13(1), 35-44.

Zeidi, M. I., Morshedi, H., \& Shokohi, A. (2021). Predicting psychological factors affecting regular physical activity in hypertensive patients: Application of health action process approach model. Nursing Open, 8(1), 442-452.

http://doi.org/10.1002/nop2.645

Othman, S., \& Essau, A. C. (2019). Adolescent Health Risk Behaviors and Mental Health: Evidence From the Malaysian National Health and Morbidity Survey 2017. Asia-Pacific Journal of Public Health, 31(8_suppl), 6S-7S. http://doi.org/10.1177/1010539519887322

Rohani, H., Eslami, A. A., Ghaderi, A., Bidkhori, M., \& Raei, M. (2016). Development and psychometric evaluation of a health action process approach inventory for healthful diet among type 2 diabetes patients. International Journal of Preventive Medicine, 2016APRIL. http://doi.org/10.4103/2008-7802.181333

Sonia, M. (2020). Mental health and emotional impact of COVID-19: Applying Health Belief Model for medical staff to general public of Pakistan. Brain, Behavior and Immunity, 2829(January).

Tahmassian, K., \& Moghadam, N. J. (2011). Relationship between self-efficacy and symptoms of anxiety, depression, worry and social avoidance in a normal sample of students. Iranian Journal of Psychiatry and Behavioral Sciences, 5(2), 91-98.

UNICEF. (2018). Situation Analysis of Adolescents in Malaysia. Salt Media Group, 4(3), 57-71. Warner, E., Nannarone, M., Smail-Crevier, R., Manuel, D., Manuel, D., Manuel, D., ... Wang, J. 
L. (2020). The relationship between depression risk perception and self-help behaviours in high risk Canadians: A cross-sectional study. BMC Public Health, 20(1), 1-12. http://doi.org/10.1186/s12889-020-08983-0

Wong, L. P., \& Alias, H. (2020). Temporal changes in psychobehavioural responses during the early phase of the COVID-19 pandemic in Malaysia. Journal of Behavioral Medicine, 44(0123456789), 18-28. http://doi.org/10.1007/s10865-020-00172-z

Wong, L. P., Alias, H., Fuzi, M. A. A., Omar, I. S., Nor, A. M., Tan, M. P., ... Chung, I. (2021). Escalating progression of mental health disorders during the COVID-19 pandemic: Evidence from a nationwide survey. PLOS ONE, 16(3 March), 1-14. http://doi.org/10.1371/journal.pone.0248916

Zhang, C. Q., Zhang, R., Schwarzer, R., \& Hagger, M. S. (2019). A Meta-Analysis of the Health Action Process Approach. Health Psychology, 38(April), 623-637. http://doi.org/10.1037/hea0000728 